"Coppice forests: past, present and future"

Editors: Tomas Vrska, Renzo Motta, Alex Mosseler

\title{
Comparison of assimilation parameters of coppiced and non-coppiced sessile oaks
}

\author{
Petra Holišová, Justyna Pietras, \\ Eva Dařenová, Kateřina \\ Novosadová, Radek Pokorný
}

\begin{abstract}
Coppice forest is an alternative to high forest mainly aimed at the production of firewood with a short rotation period. A new interest in this silvicultural system has arisen with the demand for renewable energy resources. Exploiting the existing root system of the stump, sprouts are advantaged over plants of seed origin, and this advantage could induce changes at the level of a photosynthetic apparatus, especially in young plants. This paper presents a comparison of the photosynthetic ability of young sprouts, young seedlings and mature trees of sessile oak (Quercus petraea (Matt.) Liebl.) growing in a forest stand managed as a coppice-with-standards in the southeast of the Czech Republic. The basic photosynthetic characteristics and transpiration rate at the leaf level were determined using gas-exchange measurement techniques. Data taken in non-limiting conditions were compared with those obtained under limiting soil moisture. The results revealed no differences between the measured parameters of sprouts, seedlings and old trees in non-limiting conditions. Contrastingly, sprouts had the highest photosynthetic capacity and transpiration during drought due to their ability to maintain a higher stomatal conductance as compared with seedlings and old trees. This suggests a better drought tolerance of sprouts compared to seedlings.
\end{abstract}

\section{Keywords: Drought, Photosynthesis, Sprouts, Seedlings}

Europe was investigated by Matula et al. (2012) and Šplíchalová et al. (2012). They reported that the stump sprouting ability of Quercus petraea (Matt.) Liebl. decreased with increasing stump diameter and age. Contrariwise, Carpinus betulus (L.) and Tilia cordata (Mill.) resprouted well from stumps of all diameters. A faster growth rate of sprouts, compared to trees of seed origin, leads to an earlier growth culmination and a shorter rotation period that can range from 5 to 40 years, depending on the purpose. For example, a 5-year rotation period is usually taken for the production of wicker from willow, 15 years for oaks to obtain tan barks and 40 years for fuel production (Cotta 1845). Coppice management provides sustainable production of
Global Change Research Centre, Academy of Sciences of the Czech Republic, Belidla 986/4a, CZ-603 00 Brno (Czech Republic)

@ Petra Holišová (holisova.p@czechglobe.cz)

Received: Aug 26, 2015 - Accepted: Feb 11, 2016

Citation: Holišová P, Pietras J, Darenová E, Novosadová K, Pokorný R (2016). Comparison of assimilation parameters of coppiced and non-coppiced sessile oaks. iForest 9: 553-559. - doi: 10.3832/ifor1824-009 [online 2016-03-25]

Communicated by: Tomas Vrska thin stems of lower quality (mainly used as firewood) as compared with those from high forests, with a lower financial profit (Fujimori 2001); however, in terms of costs for forest cultivation, coppice is cheaper than high forest (Kneifl et al. 2011).

Interest in coppice management has recently arisen after the claim of the European Union to increase the proportion of energy obtained from renewable resources and to reduce the consumption of fossil fuels (Kuiper et al. 1998). Short-rotation coppices are often established for afforestation of unused agricultural soils and restoration of landfills (Nixon et al. 2001). The most frequently claimed advantage of coppice is an increase in the overall biodiversity of the site, especially in terms of heliophile forest species (Spitzer et al. 2008, Van Calster et al. 2007, Baeten et al. 2009). Due to its low managing costs, coppice seems a valuable alternative for small- and medium-sized-forest owners, as well as for the regeneration of stands where seedling establishment is difficult. For example, fast-growing sprouts can be used for soil stabilization on steep slopes (Roy \& Morgan 2011). On the other hand, coppice has several disadvantages compared with high forests, such as the lower quality of timber production, the reduced genetic diversity of sprouts as compared to seedlings, that may lead to a decreased plasticity of the 
Tab. 1 - Age and mean values \pm standard deviations of basic characteristics of three studied groups of sessile oak measured in $2014(n=10)$. $(H)$ : plant height; $\left(D_{0.1}\right)$ : sprouts and seedlings stem diameter $10 \mathrm{~cm}$ above the ground/stump base; (DBH): the old trees stem diameter at breast height; (LA): plant leaf area.

\begin{tabular}{lcccc}
\hline Group & $\begin{array}{c}\text { Age } \\
\text { (years) }\end{array}$ & $\begin{array}{c}\mathrm{H} \\
(\mathrm{m})\end{array}$ & $\begin{array}{c}\mathbf{D}_{0.1} \text { or } \mathrm{DBH} \\
(\mathrm{mm})\end{array}$ & $\begin{array}{c}\text { LA } \\
\left(\mathrm{m}^{2} \text { plant }^{-1}\right)\end{array}$ \\
\hline sprouts & 5 & $2.6 \pm 0.4$ & $32.0 \pm 6.5$ & $3.2 \pm 0.9$ \\
seedlings & 5 & $1.7 \pm 0.3$ & $15.2 \pm 1.8$ & $0.7 \pm 0.2$ \\
branches & 77 & $17.1 \pm 1.2$ & $256.7 \pm 36.3$ & - \\
\hline
\end{tabular}

stand in terms of response to environmental constraints (Lloret et al. 2004). Moreover, natural regeneration from seedlings can be hampered by sprouts in stands of fast-growing broadleaved species (Vartiamäki 2009). Finally, the more frequent removal of the standing biomass in coppice as compared with high forests may lead to an impoverishment of soil nutrients (Kadavý et al. 2011).

This paper is focused on the comparison under different soil moisture conditions over two growing seasons of the photosynthetic ability and assimilation characteristics of young sprouts, young seedlings and mature trees of sessile oak (Quercus petraea (Matt.) Liebl.) growing in a coppice-with-standards forest located in the southeastern Czech Republic. Our starting hypothesis was that young oak sprouts have higher photosynthetic rate due to the possibility of using resources from the existing stump root system (Sakai \& Saka 1998, Von Fircks \& Sennerby-Forsse 1998, Lloret et al. 2004, Dickmann 2006).

\section{Material and methods}

\section{Site description}

The stydy site of Sobešice is located in the southeast of the Czech Republic ( $49^{\circ}$ $14^{\prime} 42^{\prime \prime} \mathrm{N}, 16^{\circ} 35^{\prime} 59^{\prime \prime} \mathrm{E}, 355 \mathrm{~m}$ a.s.l.) in the Training Forest Enterprise Krrtiny of the Mendel University in Brno. This site is characterized by a mean annual temperature of $7.5{ }^{\circ} \mathrm{C}$ and a mean annual precipitation from 550 to $650 \mathrm{~mm}$. A study area of $200 \times$ $200 \mathrm{~m}$ was established in 2009/2010 in a 73 year-old oak forest, where $95 \%$ of the total number of trees was sessile oak of predominantly coppiced origin. The stand was characterized by the presence of seedlings naturally regenerated from seeds of left standards and sprouts grown as a multistem coppice from stumps, with an ave rage of 12 sprouts per stump. The area was

divided into 16 square-shaped plots with an area of $2500 \mathrm{~m}^{2}$ differing in felling intensity, i.e., from clearcut plots $(100 \%$ of trees harvested) to medium-harvested plots ( $76 \%$ of trees harvested). The aim of the treatment was to convert the existing forest into copferent stand density. More detailed description of the conversion procedures is in Kadavý et al. (2011). The different stand density of the plots did not affect assimilation parameters at the leaf level and therefore it was not reflected in this study. In harvested to compare their biometric characteristics. The diameter at breast height (DBH) and tree height of ten old trees were measured for each plot (Tab. 1).

\section{In situ measurement}

The in situ physiological measurements were carried out during three days of the growing season $2013\left(20^{\text {th }}\right.$ June, $1^{\text {st }}$ August, measurements along the growing seasons of the following variables: air temperature using a Minikin RTHi (EMS, Brno, CZ), and (EMS, Brno, CZ). Soil temperature at a depth of $1.5 \mathrm{~cm}$ and the soil volumetric the ground surface were monitored during the measuring days using the TPD32 penetrate thermometer $\left({ }^{\circ} \mathrm{C}\right.$ - Omega, $\left.\mathrm{CZ}\right)$ and $\left(\mathrm{m}^{3} \mathrm{~m}^{-3}\right.$ - Delta-T Devices, UK). Four plants from each group (young sprouts, young seedlings and lower branches of old trees) were randomly selected within the plot. On every plant, a sun-exposed and fully developed leaf without sign of damage was measured at 9:00-12:0 a.m. The measurement was repeated on the same leaf in the pice and coppice-with-standards with dif2014, ten sprouts and ten seedlings were $5^{\text {th }}$ September) and two days of $2014\left(17^{\text {th }}\right.$ June, $8^{\text {th }}$ August). Days with different level of drought stress were chosen based on $\left({ }^{\circ} \mathrm{C}\right)$ and relative humidity (\%), measured precipitation $(\mathrm{mm})$ using a MetOne 380 water content in the range $0-6 \mathrm{~cm}$ below the ThetaProbe ML2X soil moisture sensor

Tab. 2 - Mean values \pm standard deviations of soil volumetric water content (SWC, $n=$ $60)$, soil temperature $\left(T_{s}, n=60\right)$, vapor pressure deficit based on leaf temperature (VPD, $n=12)$ and leaf temperature $\left(T_{L}, n=12\right)$ measured in 2013 and 2014.

\begin{tabular}{lrccc}
\hline Date & $\begin{array}{c}\text { SWC } \\
\left(\mathrm{m}^{3} \mathrm{~m}^{-3}\right)\end{array}$ & $\begin{array}{c}\boldsymbol{T}_{\mathrm{s}} \\
\left({ }^{\circ} \mathrm{C}\right)\end{array}$ & $\begin{array}{c}\text { VPD } \\
(\mathbf{k P a})\end{array}$ & $\begin{array}{c}\boldsymbol{T}_{\mathrm{L}} \\
\left({ }^{\circ} \mathrm{C}\right)\end{array}$ \\
\hline 20 Jun 2013 & $21.4 \pm 6.2$ & $27.1 \pm 2.4$ & $1.6 \pm 0.2$ & $34.7 \pm 0.8$ \\
1 Aug 2013 & $8.0 \pm 1.7$ & $26.6 \pm 3.7$ & $2.2 \pm 0.3$ & $30.5 \pm 0.7$ \\
5 Sept 2013 & $14.7 \pm 3.2$ & $20.7 \pm 1.9$ & $1.3 \pm 0.1$ & $25.3 \pm 0.8$ \\
17 Jun 2014 & $7.2 \pm 1.4$ & $18.4 \pm 1.5$ & $2.0 \pm 0.2$ & $24.9 \pm 0.7$ \\
8 Sept 2014 & $17.3 \pm 3.8$ & $20.9 \pm 1.9$ & $1.5 \pm 0.2$ & $28.4 \pm 0.7$ \\
\hline
\end{tabular}

next measuring day of the growing season. Assimilation parameters, such as the lightsaturated $\mathrm{CO}_{2}$ assimilation rate $\left(A_{\max }\right)$, the stomatal conductance $\left(g_{s}\right)$ and the transpiration rate $(E)$ were measured using a gasexchange system (LI-6400, LI-COR, USA). The leaves were exposed to the same air flow rate $(500 \mu \mathrm{mol} \mathrm{s})^{-1}$, the ambient $\mathrm{CO}_{2}$ concentration $\left(400 \mu \mathrm{mol} \mathrm{CO} \mathrm{mol}^{-1}\right)$ and the saturated photosynthetic photon flux density (PPFD, $1400 \mu \mathrm{mol}$ photons $\mathrm{m}^{-2} \mathrm{~s}^{-1}-\mathrm{LI}$ 6400-2 LED light source, LI-COR, USA) in the measuring chamber during all the sampling days. The saturated level of PPFD was chosen high enough so as the $\mathrm{CO}_{2}$ assimilation rate $(A)$ did not increase further above this level, and the measured leaves were commonly exposed to this level during sunny days. Temperature and air humidity in measuring chamber followed the actual environmental conditions. The relationship between $A$ and the intercellular concentration of $\mathrm{CO}_{2}\left(C_{i}, A-C_{i}\right.$ response curve $)$ at a saturated PPFD $\left(1400 \mu \mathrm{mol}\right.$ photons $\left.\mathrm{m}^{-2} \mathrm{~s}^{-1}\right)$ was recorded. $A-C_{i}$ response curves were not measured only in the first sampling day ( $20^{\text {th }}$ June), The $A-C_{i}$ response curve started at ambient $\mathrm{CO}_{2}$ concentration $(400 \mu \mathrm{mol}$ $\mathrm{CO}_{2} \mathrm{~mol}^{-1}$ ), decreased stepwise to 200,100 , $50 \mu \mathrm{mol} \mathrm{CO} \mathrm{mol}^{-1}$ and then increased to $700,1500 \mu \mathrm{mol} \mathrm{CO}_{2} \mathrm{~mol}^{-1}$. The values of the $A-C_{i}$ response curves were used for the estimation of the light and $\mathrm{CO}_{2}$-saturated $\mathrm{CO}_{2}$ assimilation rate $\left(A_{\text {sat }}\right)$, the rates of in vivo Rubisco carboxylation $\left(V_{\text {cmax }}\right)$, electron transport $\left(J_{\max }\right)$ and triose phosphate utilisation (TPU). The equations of Farquhar et al. (1980) with modification of the Michaelis-Menten constants of Rubisco by Harley et al. (1992) were used for $A-C_{i}$ response curve analyses.

\section{Statistical analysis}

The obtained data were tested for normality and homogeneity of variances. Twoway analysis of variance (ANOVA) was performed to evaluate the differences in the mean values among different groups (sprouts, seedlings and branches), among different date of measurement and their dependence. Differences among means were tested using the Tukey's post-hoc test $(\alpha=0.05)$. All statistical tests were performed using the software package SigmaPlot ${ }^{\circledast}$ version 11.0 (Systat Software, Inc., USA).

\section{Results}

The drought conditions occurred in August 2013 and June 2014 were characterized by low soil volumetric water content (less than $10 \mathrm{~m}^{3} \mathrm{~m}^{-3}$ ) and a high vapor pressure deficit (VPD). The drought in August 2013 was accompanied by higher temperature as compared with June 2014 (Tab. 2). The dry weather induced a significant reduction in $g_{s}$ (Fig. 1) and an increase in the limitation of $\mathrm{CO}_{2}$ diffusion into the leaf, as revealed by the decreasing ratio between the intercellular and air $\mathrm{CO}_{2}$ concentrations $\left(C_{i} / C_{a}\right.$ - Fig. 1). The low $g_{s}$ also caused a 
Fig. 1 - Mean values \pm standard deviations $(n=4)$ of stomatal conductance $\left(g_{s}\right)$ measured under ambient $\mathrm{CO}_{2}$ concentration $400 \mu \mathrm{mol} \mathrm{CO}_{2} \mathrm{~mol}^{-1}$, ratio between intercellular and air $\mathrm{CO}_{2}$ concentration $\left(\mathrm{C}_{\mathrm{i}} / \mathrm{C}_{\mathrm{a}}\right)$ and transpiration rate based on gas exchange measurement $(E)$ in 2013 and 2014 conducted on three studied groups (sprouts, seedlings and lower branches of old trees) of sessile oak.

Fig. 2 - Mean values \pm standard deviations $(n=4)$ of light-saturated $\mathrm{CO}_{2}$ assimilation rate $\left(A_{\max }\right)$ and lightand $\mathrm{CO}_{2}$-saturated $\mathrm{CO}_{2}$ assimilation rate $\left(\mathrm{A}_{\text {sat }}\right)$ during two years of measurements conducted on three studied groups (sprouts, seedlings and lower branches of old trees) of sessile oak.
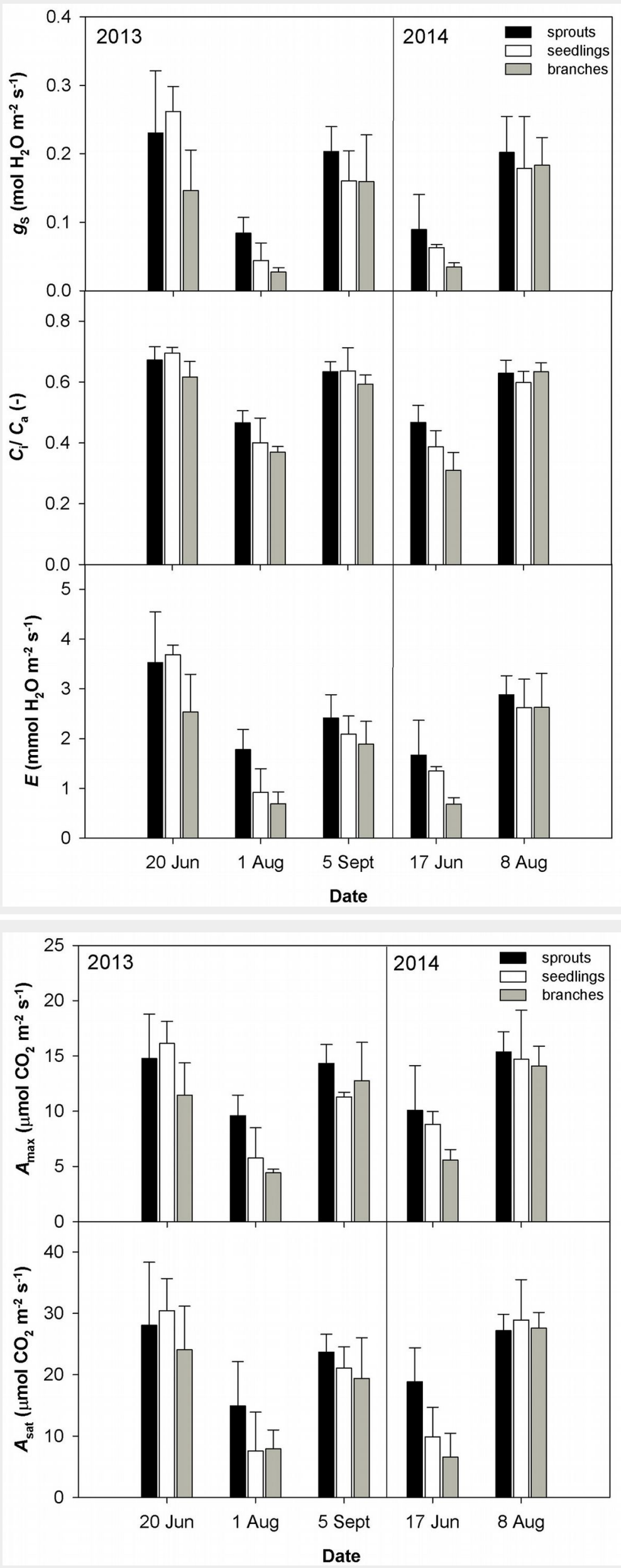


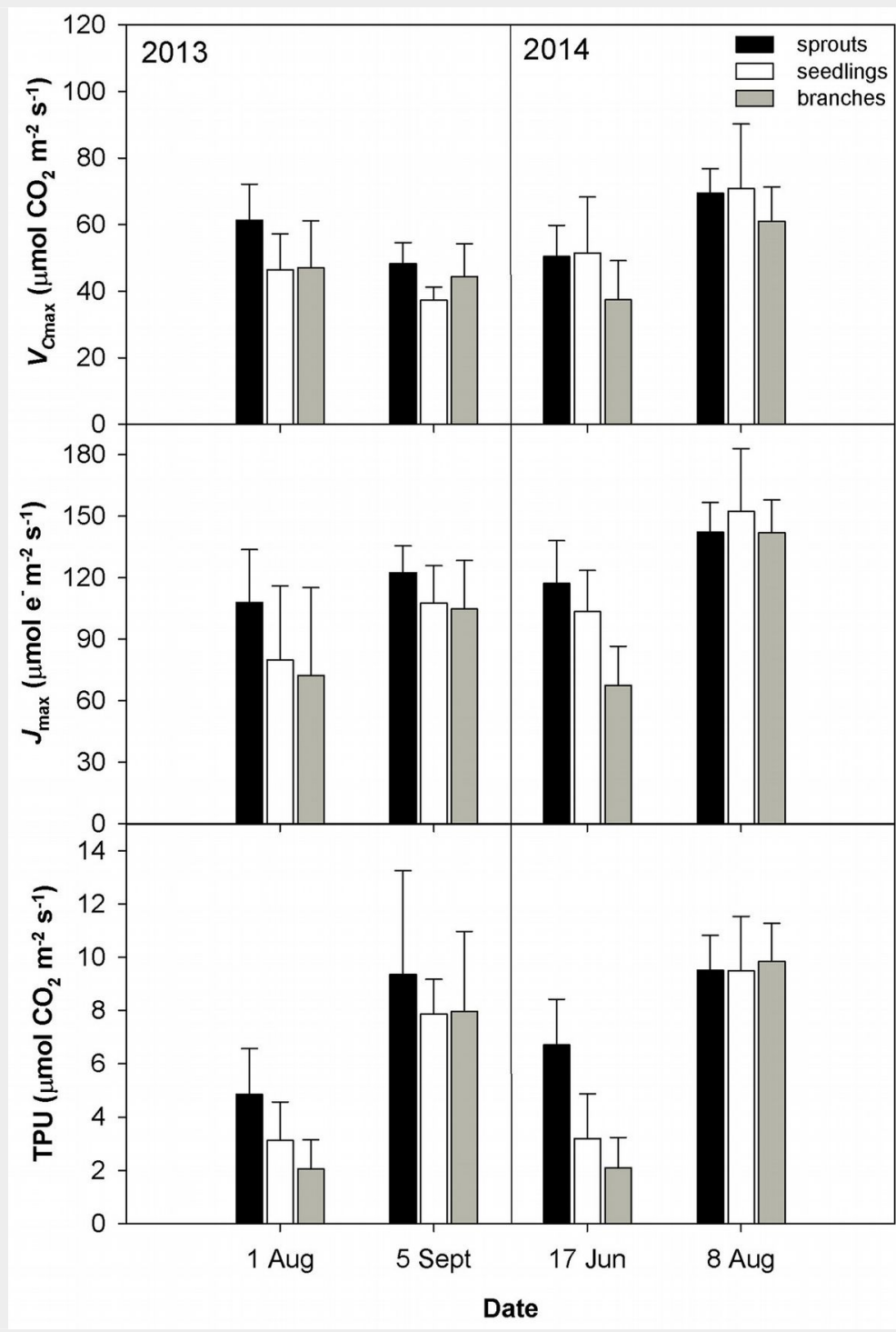

Fig. 3 - Mean values \pm standard deviations $(n=4)$ of in vivo Rubisco carboxylation rate $\left(V_{c_{\max }}\right)$, electron transport rate $\left(J_{\max }\right)$ and rate of triose phosphate utilisation (TPU) during two years of measurements conducted on three studied groups (sprouts, seedlings and lower branches of old trees) of sessile oak.

decline in $E$ (Fig. 1). The drought conditions 2013. In 2014, $V_{C \max }$ was approximately $23-$ creased during drought more than $J_{\max }$ and

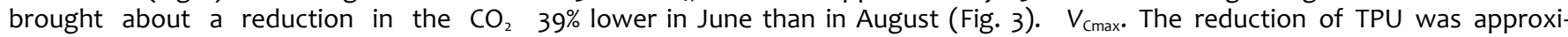
assimilation rate $\left(A_{\max }, A_{\text {sat }}\right.$ - Fig. 2). $A_{\max } J_{\max }$ was reduced by drought in both years; mately $29-79 \%$, the lowest being in sprouts and $A_{\text {sat }}$ were lower in the hot and dry however, its reduction was significant only and the highest in branches (Fig. 3 ). August 2013 than in the dry June 2014. The in 2014 (Fig. 3). The rate of utilization of The A-C response curves in the hot and $V_{C \max }$ seemed not to respond to drought in the created triose phosphates (TPU) de- dry days of August 2013 showed a reversed

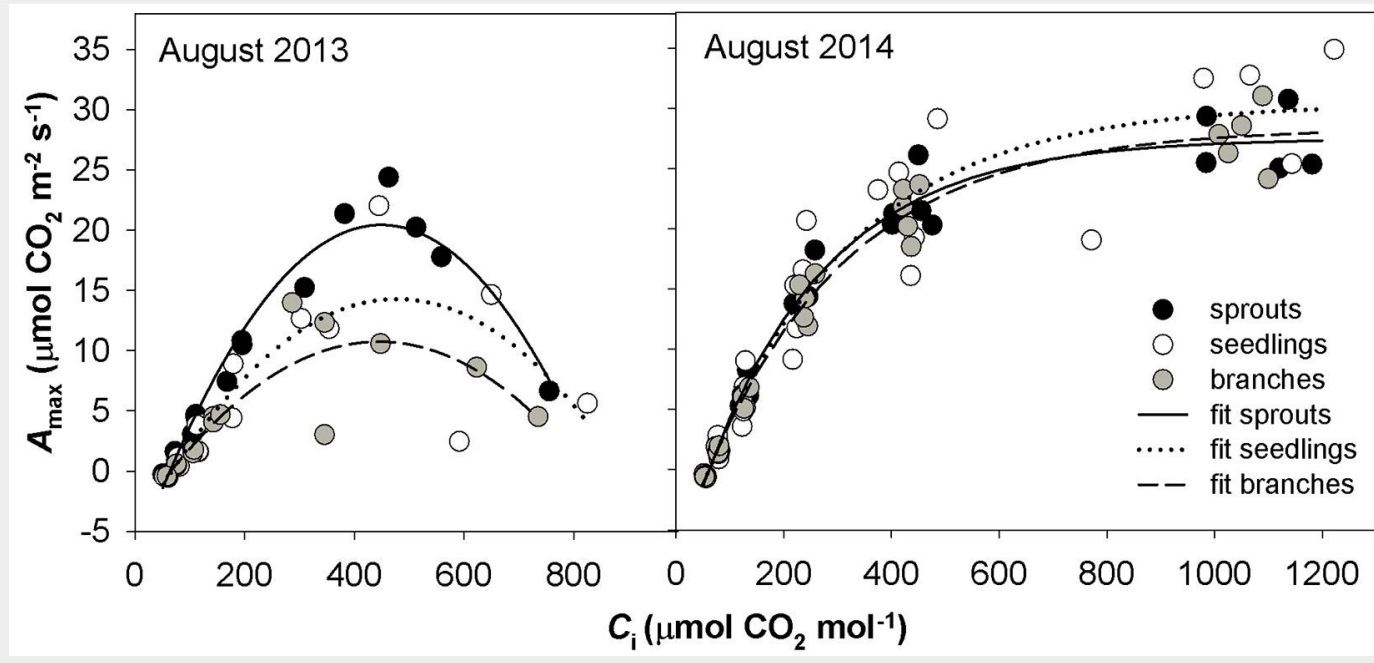

Fig. 4 - The relationship between light-saturated $\mathrm{CO}_{2}$ assimilation rate $\left(A_{\max }\right)$ and intercellular $\mathrm{CO}_{2}$ concentration $\left(C_{\mathrm{i}}\right)$ under drought in August 2013 and in moisture-normal August 2014 in three studied groups of sessile oaks. The graphs indicate individual measured values and their fits. 
Fig. 5 - The relationship between $\mathrm{CO}_{2}$ assimilation rate $(A)$ and stomatal conductance $\left(\mathrm{g}_{\mathrm{s}}\right)$, in vivo Rubisco carboxylation rate $\left(V_{c_{\text {max }}}\right)$, electron transport rate $\left(J_{\max }\right)$ and rate of triose phosphate utilisation (TPU). The individual measured values are divided in

A measured under lightsaturated and droughtunaffected condition $\left(A_{\max }\right)$ and drought affected condition ( $A_{\max }$-drought), $A$ measured under light- and $\mathrm{CO}_{2}$-saturated and in drought-unaffected condition $\left(A_{\text {sat }}\right)$ and drought affected condition $\left(A_{\text {sat }}{ }^{-}\right.$ drought). Quadratic and linear function were used to fit data; the coefficients of determination from regression analysis are shown near to the corresponding curve.
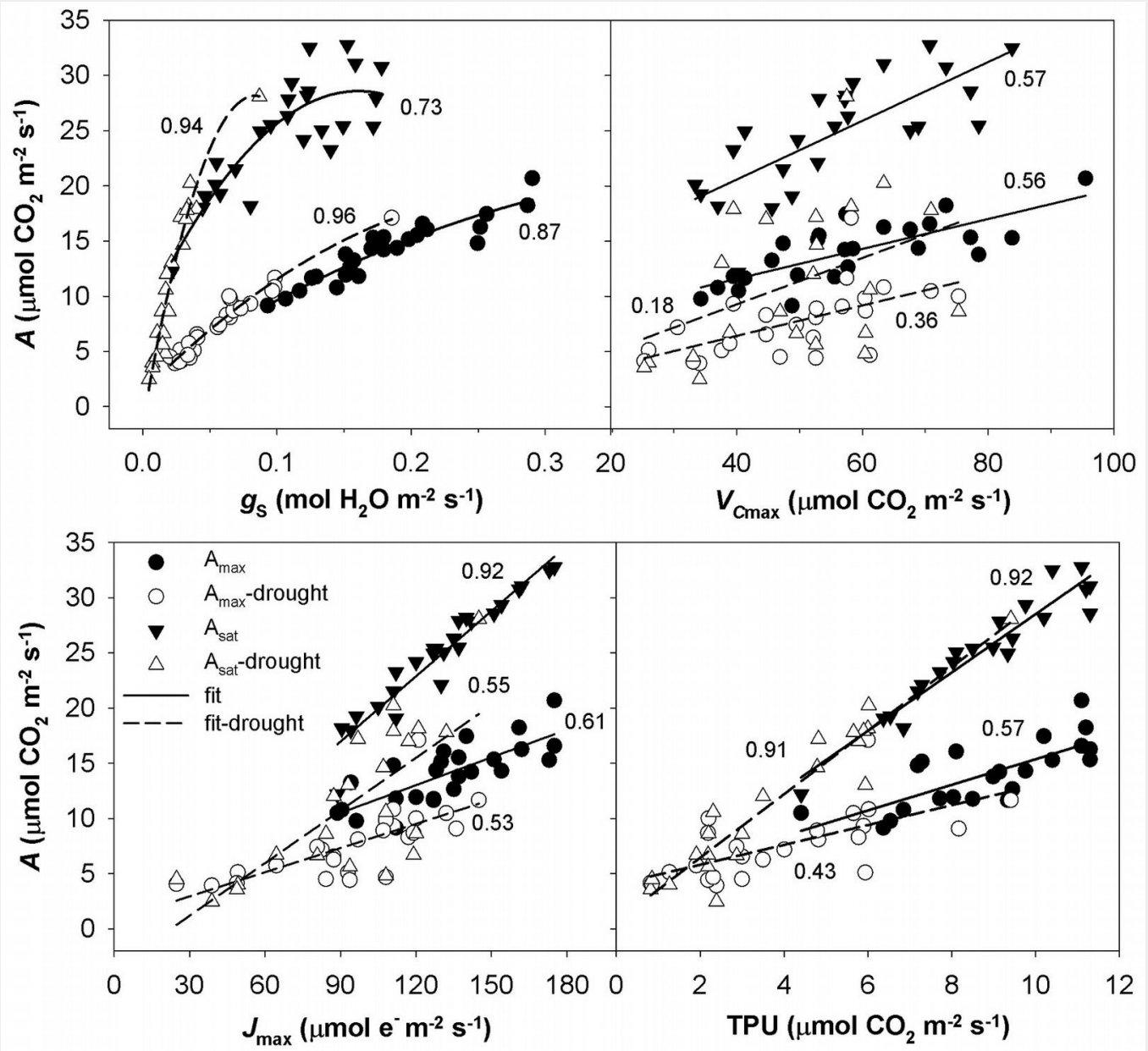

sensitivity to $C_{i}$, i.e., the rate of photosynthesis did not increase with increasing $C_{i}$ to a saturated value as for August 2014, but reached a maximum value and started to decrease (Fig. 4). The A-C $C_{i}$ response curves measured in September 2013 were similar to those taken in August 2014. Not all $A-C_{i}$ response curves observed for June 2014 showed a reversed sensitivity to $C_{i}$ as in the case of August 2013. To understand which process controls the photosynthesis, a pairwise correlation analysis using the parameters $A_{\max }, A_{\text {sat }}$ and $g_{s}, J_{\max }, V_{c_{\max }}$ and TPU was conducted (Fig. 5). $A_{\max }$ resulted tightly correlated with $g_{s}$, while $A_{\text {sat }}$ was correlated with $g_{s}$ only in the case of drought-affected values. $A_{\max }$ and $A_{\text {sat }}$ showed moderate dependence on $V_{c_{\max }}$ only in drought-unaffected months. A high correlation was found between droughtunaffected $A_{\text {sat }}$ and $J_{\max }$. Both droughtaffected and drought-unaffected $A_{\text {sat }}$ highly depended on TPU.

Differences in the measured parameters between sprouts, seedlings and lower branches of mature trees were low in the non-dry parts of the growing season (June and September 2013, August 2014). However, such differences increased under drought (August 2013 and June 2014) regardless of the time along the growing season. Under drought conditions, sprouts usually showed the highest values of the studied parameters, and the branches showed the lowest. The greatest differences between the studied groups were found for $A_{\text {sat }}, T P U, g_{s}$ and the lowest for $V_{\text {cmax }}$ (Fig. 1, Fig. 2, Fig. 3).

\section{Discussion}

Our starting hypothesis that young oak sprouts have higher photosynthetic activity as compared to other groups was not confirmed; however, sprouts showed some indication of better coping with drought stress.

Compared with seedlings, sprouts are characterized by a faster above-ground growth during early development (Herve \& Ceulemans 1996, Liberloo et al. 2009, Drake et al. 2012), although this does not entails a higher photosynthetic ability of sprouts. Indeed, seedlings allocate more assimilated carbon to below-ground biomass and root development than plants from coppicing (Drake et al. 2009). Therefore, seedlings can have the same or even a higher photosynthetic rate than sprouts, though their above-ground growth can be smaller (Drake et al. 2009).

In this study, significant differences in the measured assimilation parameters among sprouts, seedlings and branches of mature trees were observed only during periods of drought. Decreased $\mathrm{CO}_{2}$ diffusion from the atmosphere to the site of carboxylation due to stomatal closure is generally considered the main cause for decreased photosynthesis under mild to moderate water deficit (Chaves et al. 2003, Flexas et al. 2006). Different $g_{s}$ under drought between sprouts and seedlings can be caused by different root absorptive area and root depth. Under drought conditions, sprouts benefit from the developed root system, that allows a higher water uptake than that of seedlings (Lloret et al. 2004). A lower water limitation and a higher water potential of sprouts compared to seedlings was also confirmed in studies describing the effect of drought after wildfire on seedlings and sprouts survival (Williams et al. 1997, Clemente et al. 2005). A higher gs allowed the sprouts to maintain a higher rate of use of the assimilates, which led to a lower down-regulation of photosynthesis compared to that of seedlings and branches of old trees. Lower branches of old trees had the lowest $g_{s}$ during drought. It is known that $g_{s}$ usually declines with tree height and age, due to longer hydraulic pathways and an increase in the leaf-areato-sapwood-area ratio (Steppe et al. 2011). A greater reduction in the stomatal conductance in leaves of large trees can be observed during drought in comparison with young plants. Moreover, many sprouts on a single stump (as in our study) may create a more favorable microclimate 
by self-shading sprouts, thus overcoming hot and dry weather. Drake et al. (2009) tested the hypothesis that the disproportionate amount of below-ground biomass in coppices can change the leaf-to-air vapor pressure difference or intrinsic water-use efficiency when compared to those of seedlings, but no differences were observed.

Water deficit can diminish the photosynthesis close to zero without a decline in photosynthetic capacity $\left(A_{\text {sat }}\right)$. Down-regulation of $A_{\text {sat }}$ occurs when drought stress is too high or accompanied by another stress, such as high PPFD or heat stress (Chaves 1991). In the present study, drought occurred with high PPFD and high temperature, especially in August 2013, when $A_{\text {sat }}$ was mostly down-regulated. In such cases the products of photochemical reaction overcomes the capacity for their utilization and insufficient inorganic phosphate $\left(P_{\mathrm{i}}\right)$ regeneration limits ATP production that affects electron transport and RuBP regeneration (Harley \& Sharkey 1991). Regression analysis showed that $A_{\text {sat }}$ was dependent on $J_{\max }$ and TPU under drought-unaffected condition. Drought led to the disappearance of $A_{\text {sat }}$ dependence on $J_{\max }$, but dependence on TPU remained and dependence on $g_{s}$ was developed (Fig. 5), although this relationship is unusual during measurements in high $C_{\mathrm{i}}$. These conditions led to atypical course of $A-C_{i}$ response curves, especially in August 2013 (Fig. 4). Harley \& Sharkey (1991) explained the reversed sensitivity of photosynthesis to $C_{i}$ by suppressed photorespiration in high $C_{\mathrm{i}}$ that does not allow $P_{\mathrm{i}}$ regeneration in chloroplasts, which would lead to alleviation of $P_{\mathrm{i}}$-limitation. Response of plant to drought is very complex process and stomatal closure is not the only regulatory mechanism of photosynthesis. A water deficit reduces the flow rate in the phloem and also reduces the movement of assimilates from mesophyll (Ruehr et al. 2009). The recent assimilates are accumulated in source leaves, the rate of triose phosphates utilization is reduced and can be followed by down-regulation of the assimilation capacity. Stomata can respond to changes in mesophyll metabolism, so their dependency on assimilation capacity can be observed (Farquhar \& Sharkey 1982).

\section{Conclusion}

Although sprouts had a greater aboveground biomass than seedlings of the same age, their photosynthetic ability at the leaf level was not higher than that in seedlings or old trees in water non-limiting conditions. On the other hand, a larger root system of sprouts, as compared to seedlings, likely enabled them to maintain a higher stomatal conductance during drought and led to a lower down-regulation of $\mathrm{CO}_{2}$ assimilation. This study showed better drought tolerance of sprouts compared to that of seedlings.

\section{Acknowledgements}

This work was supported by the Ministry of Education, Youth and Sports of CR within the National Sustainability Program I (NPU I), grant number LO1415 and by the project "Coppice as a production and biological alternative for the future" (Reg. No. CZ.1.07/2.3.00/20.0267), funded by the EU and the government of the Czech Republic.

\section{References}

Baeten L, Bauwens B, De Schrijver A, De Keersmaeker L, Van Calster H, Vandekerkhove K, Roelandt B, Beeckman H, Verheyen K (2009). Herb layer changes (1954-2000) related to the conversion of coppice-with standards forest and soil acidification. Applied Vegetation Science 12: 187-197. - doi: 10.1111/j.1654-109X.2009.01 013.x

Chaves M (1991). Effects of water deficits on carbon assimilation. Journal of Experimental Botany 42 (1): 1-16. - doi: $10.1093 / \mathrm{jxb} / 42.1 .1$

Chaves M, Maroco J, Pereira J (2003). Understanding plant responses to drought - from genes to the whole plant. Functional Plant Biology 30: 239-264. - doi: 10.1071/FP02076

Clemente AS, Rego FC, Correia OA (2005). Growth, water relations and photosynthesis of seedlings and resprouts after fire. Acta Oecologica 27: 233-243. - doi: 10.1016/j.actao.2005. 01.005

Cotta H (1845). Handbook of silviculture. Arnoldifchen Buchhandlung, Dresden und Leipzig, pp. 102-151. [in German]

Del Tredici P (2001). Sprouting in temperate trees: a morphological and ecological review. The Botanical Review 67: 121-140. - doi: 10.1007/ BF02858075

Dickmann DI (2006). Silviculture and biology of short-rotation woody crops in temperate regions: then and now. Biomass and Bioenergy 30: 696-705. - doi: 10.1016/j.biombioe.2005. 02.008

Drake PL, Mendham DS, White DA, Ogden GN (2009). A comparison of growth, photosynthetic capacity and water stress in Eucalyptus globulus Labill. coppice regrowth and seedlings during early development. Tree physiology 29: 663-674. - doi: 10.1093/treephys/tppoo6

Drake PL, Mendham DS, White DA, Ogden GN, Dell B (2012). Water use and water-use efficiency of coppice and seedling Eucalyptus globulus Labill.: a comparison of stand-scale water balance components. Plant and Soil 350: 221235. - doi: 10.1007/s11104-011-0897-5

Farquhar GD, Caemmerer S, Berry JA (1980). A biochemical model of photosynthetic $\mathrm{CO}_{2}$ assimilation in leaves of $\mathrm{C}-3$ species. Planta 149: 78-90. - doi: 10.1007/BF00386231

Farquhar GD, Sharkey TD (1982). Stomatal conductance and photosynthesis. Annual review of plant physiology 33: 317-345. - doi: 10.1146/annu rev.pp.33.060182.001533

Flexas J, Bota J, Galmes J, Medrano H, RibasCarbo M (2006). Keeping a positive carbon balance under adverse conditions: responses of photosynthesis and respiration to water stress. Physiologia Plantarum 127: 343-352. - doi: 10.1111/j.1399-3054.2006.00621.x

Fujimori T (2001). Ecological and silvicultural strategies for sustainable forest management.
Elsevier, Amsterdam, The Netherlands, pp. 412. [online] URL: http://books.google.com/books? id=mif6D LhlfwUC

Harley PC, Thomas RB, Reynolds JF, Strain BR (1992). Modelling photosynthesis of cotton grown in elevated $\mathrm{CO}_{2}$. Plant, Cell and Environment 15: 271-282. - doi: 10.1111/j.1365-3040.1992. tboog74.x

Harley PC, Sharkey TD (1991). An improved model of $\mathrm{C}_{3}$ photosynthesis at high $\mathrm{CO}_{2}$ : reversed $\mathrm{O}_{2}$ sensitivity explained by lack of glycerate reentry into the chloroplast. Photosynthesis Research 27: 169-178. [online] URL: http://link.springer.com/article/10.1007/BFoo03 5838

Herve C, Ceulemans R (1996). Short-rotation coppiced vs. non-coppiced poplar: a comparative study at two different field sites. Biomass and Bioenergy 11: 139-150. - doi: 10.1016/09619534(96)00028-1

Kadavý J, Kneifl R, Knott R (2011). Biodiversity and target management of endangered and protected species in coppices and coppiceswith-standards included in system of Natura 2000. Methodology of establishment of experimental research plots in the conversion to coppice and coppice-with-standards and their description, Mendel University, Brno, Czech Republic, pp. 57.

Kneifl M, Kadavý J, Knott R (2011). Gross value yield potential of coppice, high forest and model conversion of high forest to coppice on best sites. Journal of Forest Science 57: 536546.

Kuiper L, Sikkema R, Stolp J (1998). Establishment needs for short rotation forestry in the EU to meet the goals of the commission's white paper on renewable energy. Biomass and Bioenergy 15: 451-456. - doi: 10.1016/So961-9534 (98)00058-0

Liberloo M, Lukac M, Calfapietra C, Hoosbeek MR, Gielen B, Miglietta F, Scarascia-Mugnozza GE, Ceulemans R (2009). Coppicing shifts $\mathrm{CO}_{2}$ stimulation of poplar productivity to aboveground pools: a synthesis of leaf to stand level results from the POP/EUROFACE experiment. New Phytologist 182: 331-346. - doi: 10.1111/j.14 69-8137.2008.02754.x

Lloret F, Penuelas J, Ogaya R (2004). Establishment of co-existing Mediterranean tree species under a varying soil moisture regime. Journal of Vegetation Science 15: 237-244. - doi: 10.1111/j. 1654-1103.2004.tbo2258.x

Matula R, Svátek M, Kurová J, Úradníček L, Kadavý J, Kneifl K (2012). The sprouting ability of the main tree species in Central European coppices: implications for coppice restoration. European Journal of Forest Research 131: 15011511. - doi: 10.1007/s10342-012-0618-5

Nixon DJ, Stephens W, Tyrrel SF, Brierley EDR (2001). The potential for short rotation energy forestry on restored landfill caps. Bioresource Technology 77: 237-245. - doi: 10.1016/S09608524(00)00081-X

Roy PC, Morgan RJ (2011). Slope stabilization and erosion control: a bioengineering approach. Taylor \& Francis Ltd., London, UK, pp. 274. Ruehr NK, Offermann CA, Gessler A, Winkler JB, Ferrio JP, Buchmann N, Barnard RL (2009). Drought effects on allocation of recent carbon: from beech leaves to soil $\mathrm{CO}_{2}$ efflux. New Phy- 
tologist 184: 950-961. - doi: 10.1111/j.1469-8137. 2009.03044.x

Sakai A, Sakai S (1998). A test for the resource remobilization hypothesis: tree sprouting using carbohydrates from above-ground parts. Annals of Botany 82: 213-216. - doi: 10.1006/anbo. 1998.0672

Spitzer L, Konvicka M, Benes J, Tropek R, Tuf IH, Tufova J (2008). Does closure of traditionally managed open woodlands threaten epigeic invertebrates? Effects of coppicing and high deer densities. Biological Conservation 141: 827837. - doi: 10.1016/j.biocon.2008.01.005 Steppe K, Niinemets Ü, Teskey RO (2011). Tree size- and age-related changes in leaf physiology and their influence on carbon gain. In: "Sizeand age-related changes in tree structure and function" (Meinzer FC, Lachenbruch B, Dawson TE eds). Springer, New York, USA, pp. 235-253. doi: 10.1007/978-94-007-1242-3_9

Splíchalová M, Adamec Z, Kadavý J, Kneifl M (2012). Probability model of sessile oak (Quercus petraea (Matt.) Liebl.) stump sprouting in the Czech Republic. European Journal of Forest Research 131: 1611-1618. - doi: 10.1007/s10342-01 2-0628-3

Van Calster $H$, Baeten L, De Schrijver A, De Keersmaeker L, Rogister J, Verheyen K, Hermy $M$ (2007). Management driven changes (19672005) in soil acidity and the understory plant community following conversion of a coppicewith-standards forest. Forest Ecology and Management 241: 258-271. - doi: 10.1016/j.foreco.20 07.01 .007
Vartiamäki H (2009). The efficacy and potential risks of controlling sprouting in Finnish birches (Betula spp.) with the fungal decomposer Chondrostereum purpureum. Dissertationes Forestales 93, pp. 31. [online] URL: http:// www.metla.fi/dissertationes/df93.htm Von Fircks $Y$, Sennerby-Forsse L (1998). Seasonal fluctuations of starch in root and stem tissues of coppiced Salix viminalis plants grown under two nitrogen regimes. Tree physiology 18: 243249. - doi: 10.1093/treephys/18.4.243

Williams JE, Davis SD, Portwood K (1997). Xylem embolism in seedlings and resprouts of Adenostoma fasciculatum after fire. Australian Journal of Botany 45: 291-300. - doi: 10.1071/BT96 030 